\title{
On Abnormal Cell-fusion in the Archegonium; and on Spermatogenesis in Polytrichum.
}

\author{
BY
}

\author{
NORMAN WALKER, \\ Assistant-Lecturer in Botany, University of Leeds.
}

With Plates XIII and XIV.

$\mathrm{T}$ the year $1908 \mathrm{~J}$. and W. van Leeuwen-Reijnvaan (12) published an 1 account of the sexual process and spermatogenesis in several species of Polytrichum in which the conclusions appeared so remarkable, that it was suggested by Professor V. H. Blackman that a re-investigation of this subject might give interesting results. Strasburger (16) also, in 1909, in commenting upon the statements of these observers, indicated that further work was necessary to set these questions beyond doubt.

$\mathrm{J}$. and W. van Leeuwen-Reijnvaan state that the number of ehromosomes present in the cells of the sporogonium is twelve, and in the sexual plant six. During the last division of the spermatogenic cells a reduction is said to take place in the number of chromosomes, and consequently each spermatid receives three, and this number will be carried by the spermatozoid. On the division of the egg mother-cell or central cell of the archegonium two cells of equal size are produced, the upper corresponding to a ventral canal cell, the lower to an egg-cell. During this division a reduction in the number of chromosomes is stated to take place, so that three is also the number received by each of these cells. While the neck of the archegonium is still closed the nuclei of the two cells are said to fuse, and the large cell resulting from this fusion is fertilized by two spermatozoids. In this way four sets of three chromosomes are brought together, and the sporophytic number is thus established.

The present investigation, which was commenced in 1909, was first directed towards the archegonium of Polytrichum and later to the last divisions in the antheridium. This led to further observations upon the division of the nucleus and upon spermatogenesis in Polytrichum formosum, Hedw., and an account of the results obtained, which differs in many respects from that of J. and W, van Leeuwen-Reijnvaan, forms the chief part of the 
present paper. In a recent contribution upon spermatogenesis in the Bryophyta by Malcolm Wilson (22) an adequate historical outline of the subject was given, and this will not be repeated here. Reference to recent work will be made in the descriptive part of the paper.

\section{Methods.}

The material was fixed in the field during June, when all stages in the development of the antheridia are present as well as both young and old archegonia. The air was removed from the tissues by means of an airpump. Zenker's mixture, acetic alcohol, and various strengths of Flemming's solution were tried as fixing reagents, but the best results were obtained by the use of Flemming's strong solution diluted with an equal volume of water. The objects were dehydrated by the glycerine method and brought gradually into cedar oil, through several mixtures of this oil and absolute alcohol. The introduction to paraffin was also gradual by means of successive baths in mixtures of the cedar oil and wax. The material cleared in this way was found to be less brittle than when chloroform was used. The stay in paraffin was made as short as possible; five or six hours usually sufficed. Sections were made of $3 \mu-6 \mu$ in thickness. In staining, the best results were obtained by Heidenhain's ironhaematoxylin method preceded by a I $2-24$ hours' treatment with a solution of Bordeaux R. Flemming's triple stain (safranin, gentian violet, and orange $G)$ gave useful results as a nuclear stain, but was found disappointing for the developing spermatozoids.

\section{The Behaviour of the EgG and Ventral Canal Cell.}

To determine this, more than a hundred archegonial rosettes of Polytrichum formosum and $P$. commune were sectionized, and in no case was a fusion between these cells observed. On the other hand, many stages in the disorganization of the large ventral canal cell were seen, and the rounding off of the lower cell only, to form the ovum. Ultimately the egg-cell is left in the lower region of the venter, and above it is sometimes seen the delicate transverse wall which originally separated the two cells. It seems probable that the appearance of fusion of the egg-cell and ventral canal cell observed by J. and W. van Leeuwen-Reijnvaan is due to their method of fixation, which they describe in detail. Before passing the archegonial rosettes into the fixative, they removed the involucral leaves and examined the rosettes with a pocket lens to determine the presence of archegonia, which were recognized by their necks. Under this treatment the delicate archegonial necks probably contract through drying a little, and squeeze the neck canal cells into the venter, in which situation they are described and figured by these observers. When the rosettes are fixed without exposure of the archegonia the canal-cells do not descend into the venter, and the 
ventral canal cell therefore is not driven towards the egg-cell, and no simulation of fusion occurs. In several hundred archegonia fixed in this way, none showed the occurrence of the neck canal cells in the venter. It seems scarcely open to doubt that the abnormal conditions referred to have induced the fusion appearances described by J. and W. van LeeuwenReijnvaan. It will be shown later that the reduction in the number of chromosomes at the last division of the spermatogenic cells does not occur in Polytrichum formosum, the species from which the above observers' figures were taken.

\section{The Nucleus in the Spermatogenic Cells.}

In young antheridia, shortly after the differentiation of the spermatogenic from the wall cells, the former cells are larger than at any subsequent stage. The cytoplasm is finely granular and contains numerous vacuoles which vary in size in different cells (Pl. XIII, Figs. I and 3). Chloroplasts which seem to be in a state of disorganization also occur (Figs. I and 4); these persist for a few cell generations, but ultimately disappear, as they are not found in the cells at the time of the last division. In a single case the presence of well-developed chloroplasts was observed in the spermatogenic cells at the apex of an older antheridium, where the better illumination would favour their occurrence. It seems probable that they owe their origin to the persistence of plastids through the intervening cell generations. Deeply stained granules of various sizes are often found scattered through the cell, and each granule is usually surrounded by a clear space (Figs. 3 and 8). The disposition of these particles is sometimes such as to suggest centrosomes (Fig. 3), and J. and W. van Leeuwen-Reijnvaan have figured similar bodies in young antheridial cells of Polytrichum formosum, and have placed this interpretation upon them. These observers state that they were able to distinguish between centrosomes and the other particles occurring in the cytoplasm by the presence of a clear halo which characterized the centrosomes. The preparations upon which the present account is based fail to show any distinction of this kind, and a careful search through many young antheridia leads to the conclusion that centrosomes are not present in the young spermatogenic cells, although, as will be shown later, centrosome-like bodies are associated with the final division of the spermatogenic nuclei.

In the spermatogenic cells the nucleus is relatively large and centrally placed. Near the centre of each nucleus is a large, deeply stained body which sometimes has a diameter of about half that of the nucleus (Fig. 3) and is designated a nucleolus by most writers upon this subject. This body resembles the nucleolus in the root-apex of Phaseolus, as described by Wager (19), both in appearance and in some degree in its behaviour during the prophase of division. In sections stained by the triple stain the nucleolus is seen to consist of a central red body, probably corresponding to the 
nucleolus in the higher plants, embedded in a violet staining substance, the chromatin. The peripheral region of the nucleus is occupied by an exceedingly delicate reticulum, and this is connected with the centrally placed nucleolus by fine threads. At the points of insertion of these threads the chromatin of the nucleolus is drawn out into minute prominences. Fig. I shows a surface view of the reticulum with droplets of chromatin at the intersections of the threads and the nucleolus lying beneath. In Fig. 2 are seen the radiating threads (the 'suspending threads' of Wager). J. and W. van Leeuwen-Reijnvaan in their account of the spermatogenic cells of Polytrichum do not describe the region of the nucleus between the nucleolus and the nuclear membrane, and in their figures leave it empty. Woodburn (23) describes a nucleus similar to that of Polytrichum in the young spermatogenic cells of Porella but makes no mention of suspending threads. In Marchantia, according to Woodburn (23), the nucleus in the resting condition 'shows an evident linin network containing relatively large lumps of chromatin in a clear nuclear sap without any nucleolus'. It seems probable that the single large nucleolus described in Porella by Woodburn, in Pellia and Mnium by Wilson, and in Polytrichum, simply represents a closer aggregation of the chromatin material than occurs in Marchantia according to Woodburn (23), and in Fegatella according to Bolleter (5), where several large lumps are found. In Polytrichum, as will be shown later, the nucleus shortly after division exhibits scattered lumps of chromatin, but this phase is soon passed over and the lumps collect to form a single central body.

Wilson's account of the nuclear reticulum in the archesporial (21) and spermatogenic cells (22) of Mnium hornum differs somewhat from the foregoing. He states that 'the nuclear network is fine and closely resembles the cytoplasm in structure, no chromatin being present in it during the resting condition'. Wilson's drawing of a spermatogenic cell (Fig. I in his paper) fails, however, to show the nuclear reticulum which he describes. This drawing agrees with certain appearances sometimes seen in the resting nuclei in young spermatogenic cells of Polytrichum (Fig. 3), where the ground substance of the nucleus presents a finely granular appearance, suggesting the possibility that the network has been masked by a fine granular substance, perhaps precipitated by the fixative. A more or less distinct reticulum, however, may generally be seen even in young cells of the antheridium, and is a constant feature of nuclei of the later cells and of the nuclei of the vegetative parts. Wilson further adds that a nucleus of this type (Fig. I in his paper and resembling Fig. 3 in the present account) can be considered characteristic of the Muscineae. With regard to its general structure the Bryophyte nucleus as described by Beer (3) in Riccia, by Van Hook (18) in Marchantia, by Woodburn (23) in Porella, and according to the present description in Polytrichum, does not appear to differ very greatly from that of the higher plants. Both in regard to the large size 
and prominence of the nucleolus-like body and in the extreme fineness of the nuclear reticulum, and in Polytrichum the presence of 'suspending threads', a close agreement is found with the nucleus in the root-tip of Phaseolus.

\section{The Formation of the Chromosomes.}

On the approach of division the nucleolus loses its compact rounded appearance, and the threads connected with it become thicker and stain very deeply (Figs. I 3 and I4). This appearance strongly suggests the direct transference of the chromatin of the nucleolus to the nuclear reticulum by way of the radiating threads. Finally the whole of the chromatin is passed to the reticulum, certain parts of which are consequently heavily loaded with this substance. Fig. I 5 shows a surface view of the reticulum in this condition. Meanwhile the chromatin appears to have increased considerably in amount. In favourable cases, after the distribution of the chromatin to the reticulum, a feebly staining matrix is seen to remain in the centre of the nuclear cavity, and still connected with the peripheral network by radiating threads (Fig. I7). This remaining part of the nucleolus becomes lost to view when the spireme is established.

The gradual advance of the chromatin from the nucleolus, along the radiating fibres to certain threads of the peripheral network, differs sharply from the simultaneous appearance of this substance in all those parts of the thread system which form the chromosomes, as described by Martins Mano (13) in Phaseolus and Solanum. Some agreement is found, however, in Polytrichum with Wager's (19) account of the behaviour of the nucleolus in Phaseolus during the prophase, where this author saw appearances which led to the conclusion that a considerable amount of the substance of the nucleolus is transferred to the chromosomes. The remaining portion of the nucleolus in the same plant was observed to divide into two lumps which travel to the poles of the spindle and ultimately disappear. Martins Mano (13) states that these polar masses are expelled into the surrounding cytoplasm. In Polytrichum a definite extrusion of chromatin was seen to take place only during the last division of the spermatogenic cells and from the resultant spermatids. These extrusions will be dealt with later.

Certain peripheral threads are now seen to be considerably thickened; between these occur fine anastomosing connexions, and already an appearance of continuity in the stout thread system can be distinguished (Fig. I6). As this thread becomes transformed into a spireme, the connecting fibres break down, and the whole structure appears to contract towards the centre of the nuclear cavity (Figs. 4 and 5 ). Meanwhile the nuclear membrane has become very indistinct. A marked elongation of the nuclear region is observed at this stage, and the clear part external to the spireme is crossed 
by delicate threads, which pass from the spireme to the cytoplasm. In some cases the spindle fibres are seen to be connected with elongate structures, probably the remains of the chloroplasts, which often partly invest the nucleus at this stage (Fig. 5). Later, when the spindle is clearly present, it is seen in most cases to possess blunt poles about which are often seen aggregations of irregular particles (Fig. 9). ${ }^{1}$ In the last division, however, the spindle fibres converge upon a single centrosome-like particle. The segmentation of the spireme to form the chromosomes is rarely found in the preparations, but it was observed in the nucleus of an early spermatogenic cell from which the stain had been removed from all parts except the spireme (Fig. 6). This mode of treatment was generally followed, owing to the greater clearness which it imparts to the chromosomes. According to J. and W. van Leeuwen-Reijnvaan, the chromosomes in Polytrichum are derived by the breaking up of the nucleolus into fragments, each fragment becoming a chromosome.

The number of chromosomes is six, and they are approximately of the same size and of a broad V shape (Fig. 7). No indications were observed of the three pairs of chromosomes of different sizes, described by $\mathrm{J}$. and $\mathrm{W}$. van Leeuwen-Reijnvaan in this species of Polytrichum. The chromosomes become arranged upon the spindle and lie flat in the equatorial plane with their ends outwards. A careful search discovered one case only where indications of longitudinal fission of the chromosomes could be observed (Fig. 8). The appearance of some of the chromosomes in Fig. 9 suggests that the separation takes place first at one end. One of the inner pairs of daughter chromosomes seen in the above figure and also those in Fig. I 8 seem to have separated first in the middle region. The sliding apart of the daughter chromosomes and their passage to the poles are probably rapidly effected, as these phases are of unusual occurrence in preparations showing very numerous nuclei in a state of division.

During the last division, while the daughter chromosomes are travelling to the poles, a relatively large deeply stained particle becomes detached from one or both of the chromosome groups; occasional dividing nuclei also occur which have reached the telophase without detaching these bodies. Fig. I9 shows this chromatin particle as it appears in a side view of the spindle, and Fig. 20 as seen in two polar views. As Fig. I 9 indicates, this body appears to separate as a viscid drop of matter from a chromosome which lags a little behind the rest. J. and W. van Leeuwen-Reijnvaan

1 Since writing the present account of the division of the nucleus in Polytrichum, a recent contribution upon this subject by C. E. Allen (1) has come into my hands. This observer deals in detail with the organization of the spindle, and describes certain polar plates and polar particles, named by him 'kinetosomes', upon which the spindle fibres are inserted. The observations made during the present investigation upon Polytrichum formosum lead to the conclusion that Allen's 'kinetosomes' are derived from the chloroplasts which are received by the early spermatogenic cells when these become differentiated from the wall-cells. 
figured these extruded particles but misinterpreted them as centrosomes, which, after occupying the poles of the spindle, have come round to the inner side of each chromosome group, and ultimately pass in amongst them and become included within the daughter nuclei.

In view of 'J. and $W$. van Leeuwen-Reijnvaan's statement that a reduction in the number of chromosomes takes place during the last division in the antheridium of Polytrichum formosum, countings were made of the chromosomes in this species during the anaphase, and the full number, six, was repeatedly found to be present (Fig. 20).

\section{The Reconstitution of the Daughter Nuclei.}

During the telophase the chromosomes become united in such a manner as to constitute a figure resembling the spireme of the prophase (Fig. 22). Many nuclei exhibit an end-to-end union of the daughter chromosomes. Fig. 2I shows an example of this where five chromosomes have become united; while in the cell on the left in Fig. 20 is a sixth chromosome which shows indications of becoming laterally united with adjoining chromosomes. Connecting threads next appear between some of the chromosomes, probably as a result of contact at certain places, followed by a pulling apart and the drawing out of viscid threads, the whole presenting the appearance of a simple reticulum (Fig. 20, cell on the right). There is no definite approximation of the chromosomes such as that observed by Fraser and Snell (7) in Vicia Faba, nor could any alveolization of the chromosomes be made out at any stage in the division of the nucleus as described by Grégoire and Wygaerts (8) and others in various plants.

The establishment of the reticulum is accompanied by a change in the distribution of the chromatin, which is now seen to leave the network and collect into small drops of various sizes (Figs. Io and II). These deeply staining drops gradually run together and form the large rounded nucleolus. Sometimes a single chromatin droplet remains for a time distinct from the main mass (Fig. I2), but ultimately this is usually taken in, thus leaving the reticulum with very little chromatin distributed upon its threads. It is probable that the last outstanding particle of chromatin is identical with the body which J. and W. van Leeuwen-Reijnvaan state is cut off from the nucleolus and extruded from the nucleus to form, by division, the centrosomes.

\section{The OCCurrence of Centrosomes.}

During the early prophase of the last division of the spermatogenic cells, the centrosome-like bodies, stated by J. and W. van LeeuwenReijnvaan to be present at all divisions, are observed for the first time in the development of the antheridium. The determination of the last division gave considerable difficulty. Except in a few cases, this is not 
diagonal as in Marchantia described by Ikeno (9), and Fegatella by Bolleter (5), consequently this easy method of distinguishing it is not available. At this time the cell-walls are thick and swollen, and stain somewhat deeply with orange G (Figs. 18-20). The contents appear more or less rounded, and the spermatogenic tissue no longer presents the well-known tessellated appearance which characterizes it in sections of younger antheridia. Countings were also made of the cells after this division, and these were found to approximate those of antheridia containing spermatids with developing spermatozoids. As a result of the final division, two spermatids are formed within each thick-walled chamber (Fig. 23).

The centrosome-like bodies, when first perceived, are situated upon opposite sides of the nucleus and appear as minute deeply stained particles of equal size, with a few delicate radiations extending from each (Figs. I3I5). According to Ikeno, these organs are present in the antheridium of Marchantia polymorpha during all the cell-divisions, and he therefore regards them as morphologically equivalent to centrosomes. During the following account this term will be used to designate these bodies. Their presence in the antheridium of Polytrichum at this stage is unmistakable, as they can be easily determined in all the cells. It was not found possible to discover their origin. No appearances were observed suggesting the extrusion of a parent particle from the nucleus. To determine this point, a differential stain is required to distinguish these structures, before they take up their position at the poles of the nucleus, from other deeply staining particles which are often observed both within the nucleus and in the cytoplasm.

When the spindle is formed, the centrosomes occupy its poles and are now much less conspicuous than during the prophase. After the completion of the division these bodies persist in the daughter-cells, one lying close to each nucleus (Fig. 23). As the time of the development of the spermatozoid approaches, the persistent centrosome increases in size (Fig. 27) and becomes highly refractive, appearing as a very conspicuous object in the spermatid. This refractive body, or blepharoplast as it may now be called, agrees with the 'stark lichtbrechender Plasmahöcker' of Strasburger (17).

In two antheridia belonging to the same rosette a nuclear division was observed, which, considering its rarity and the unusually large number of cells counted across the longitudinal section, was regarded as an extra division. In these cells the centrosome, which has already become refractive, has probably in some degree lost its normal function. This is also suggested by the fact that its division does not precede the onset of mitosis, but was found to take place in one case at the time of the formation of the chromosomes (Fig. 24); in another, not until after the formation of the spindle. In some dividing nuclei of these special antheridia the two resultant refractive bodies are seen to occupy the poles of the spindle (Fig. 25); 
in others they lie away from the spindle in other parts of the cell (Fig. 26). It seems very improbable, for the reasons already stated, that this division is of normal occurrence. If such were the case, the centrosomes would then be regarded as making their first appearance at the time of the penultimate division; and between that and the final division become refractive and lose their centrosome function. Six is again the number of chromosomes which pass to each of the daughter nuclei during this division.

The presence of centrosomes during the last cell-division in the antheridium in Polytrichum, and their persistence as blepharoplasts, is of interest in regard to Wilson's statement (22) that in Mnium hornum and Atrichum undulatum centrosomes do not occur, and that the blepharoplast in each case is derived directly from the nucleolus of the spermatid. This body, which is passed out from the nucleus, Wilson believes to have been phylogenetically derived from a centrosome. Ikeno regards Marchantia, in which he states that centrosomes are present during all cell-divisions in the antheridium, as representing in this respect a relatively primitive condition, while in other Bryophytes they are being gradually eliminated and occur only in the later cell-divisions. Miyake (14), on the other hand, fails to find centrosomes during the early divisions of Marchantia, and believes that the bodies which are found at the poles of the spindle during the last division are blepharoplasts and are not related in any way to centrosomes. Escoyez (6) in his researches on Marchantia and other Liverworts supports the views of Miyake. Woodburn, in a recent paper (23), states that he can find no evidence of the existence of centrosomes in the Liverworts which he investigated (Porella, Asterella, Marchantia, and Fegatella), or of the persistence of the body which occupies the poles of the spindle in the last division as an individual organ in the resulting sperm-cell. This observer believes that the blepharoplast originates through a condensation or aggregation of cytoplasmic material in the sperm-cell.

\section{The Formation of the Spermatozoid.}

Fig. 27 shows a spermatid before the onset of the series of changes which transform it into a spermatozoid. This cell is at first somewhat polygonal, but as spermatozoid formation progresses it becomes more and more rounded. The relatively large nucleus is usually situated somewhat to one side of the cell, and the prominent blepharoplast is embedded in the cytoplasm towards the other side. At this stage the chromatin is held in rather large masses upon the reticulum, but most of this substance soon collects to form a central nucleolus-like body (Fig. 28). The greater portion of this deeply staining substance is next seen to be passed out into the surrounding cytoplasm (Figs. 29-31), where it collects, usually in the form of two drops, in the vicinity of the blepharoplast. This body may still be easily perceived, although it commonly becomes immersed in the 
extruded chromatin and consequently does not appear in the three figures representing these changes. The nucleus now stains very feebly, and its limits are often very difficult to distinguish (Figs. 29-3I). In an occasional spermatid the extruded substance is collected into one drop, and there can be little doubt that this single mass of chromatin, and consequently the two masses normally present, corresponds to the "chromatoiden Nebenkörper ' observed in Marchantia by Ikeno (9), the origin of which he was unable to determine. It agrees also with the 'limosphere' described by Wilson (22) in Mnium hornum and in Atrichum undulatum.

In Mnium Wilson states that the 'limosphere' originates through the coalescence of rod-like structures derived from the nucleolus, and in Atrichum it is derived directly from the nucleolus. This observer believes that $\mathrm{J}$. and $\mathrm{W}$. van Leeuwen-Reijnvaan misinterpreted these rod-like bodies as three chromosomes, and upon this founded their statement regarding reduction. As these rod-like structures do not occur in Polytrichum, it therefore follows that Wilson's explanation regarding the observations of $\mathrm{J}$. and W. van Leeuwen-Reijnvaan does not apply.

In those spermatids where the blepharoplast is embedded in the extruded chromatin, it soon becomes free and is next seen to lie at varying distances from this substance (Figs. 32 and 33). In Fig. 32 the blepharoplast is the larger particle underlying one end of the nucleus. Meanwhile, a prominent organ, which when mature takes the form of a curved band, has now commenced its development at the periphery of the spermatid. This structure is first organized in the vicinity of the rounded masses of extruded chromatin, which at this stage appear hollow, the substance in the interior of each mass staining very faintly. The resemblance between these deeply staining bodies and the single 'limosphere' described by Wilson is now apparent, while the difference in number may probably be accounted for by the much larger amount of chromatin which is passed out of the nucleus in Polytrichum. With regard to the function of these bodies, their intimate association with the band-like structure and the similarity in their capacity for stain suggest that they contribute some of their substance to its formation. At a later stage, when this band is completely formed, only one deeply stained vesicle remains (Figs. 34-6) ; the other probably owes its disappearance in some degree to the transference of its substance to the developing band. This interpretation of its disappearance is supported by the spermatid shown in Fig. 32, where that part of the band in close proximity to the diminishing vesicle is seen to develop first.

The spermatid, hitherto a compact protoplasmic body, now develops numerous large vacuoles and increases considerably in size. The nucleus stains more deeply and contains a central nucleolus-like structure (Fig. 34). At the same time the developing band has become extended towards, and finally reaches, the blepharoplast. This strongly arched band now connects 
the blepharoplast with the remaining deeply staining vesicle, and in all cases the nucleus is enclosed within the arch (Figs. 34-6). Fig. 34 shows a side view, and Fig. 35 a dorsal view, of a spermatid at this stage. The term dorsal is used in Belajeff's (4) sense and refers to the side of the spermatid near which the nucleus lies.

The arched band of the Pelytrichum spermatid is probably homologous with the ' cytoplasmatischer Fortsatz' described by Ikeno in Marchantia (9). In the latter plant this structure appears as a short arched band which connects the blepharoplast with the nucleus, and it is significant that, at the time of its formation, the 'chromatoide Nebenkörper', which has been situated in this region, disappears. It seems probable that the 'Nebenkörper' has been concerned in some way in the formation of the 'cytoplasmatischer Fortsatz'. There is, however, a marked difference between Marchantia and Polytrichum in the situation of the 'Nebenkörper'. In the Liverwort this body occurs between the blepharoplast and the nucleus, and the curved band, which is correspondingly short, is developed between the two in such a manner as to connect them. In Polytrichum, the 'Nebenkörper' is situated on the posterior side of the nucleus (Fig. 36), and the arched band is consequently much longer and extends from the 'Nebenkörper' to the blepharoplast in front, including the nucleus in its arch. In this respect Fossombronia agrees with Marchantia. In the former plant, Humphrey (11) uses the term 'middle piece' for the connecting band, or the ' cytoplasmatischer Fortsatz' of Ikeno.

The difficulty experienced in tracing the changes which take place in the spermatid in the Bryophyta is indicated by the various conflicting statements which have been made with regard to the 'Nebenkörper'. Woodburn (23) asserts that in Marchantia ' no body corresponding in size and appearance to the "Nebenkörper" of Ikeno was found'. Arens (2) similarly asserts that no body of this kind occurs in Polytrichum juniperimum; while $\mathrm{J}$. and $\mathrm{W}$. van Leeuwen-Reijnvaan state that a body corresponding to Ikeno's 'Nebenkörper' is present, but disappears before the spermatozoid is ripe. According to the present investigation, in Polytrichum the 'Nebenkörper' does not disappear, but persists in the ripe spermatozoid. Some explanation of these opposing statements is probably found in the difficulty encountered in staining the spermatids at the time when the most important changes are taking place.

The 'Nebenkörper' of Ikeno, which is conspicuous in the spermatids of Marchantia, Pellia, Fegatella, Fossombronia, Atrichum, Mnium, and Polytrichum, is probably functional in these plants and is concerned in the formation of the band-like body along which the nucleus extends itself. This conclusion is strongly suggested by the constant and definite connexion between these structures ('Nebenkörper' and arched band) in Polytrichum (Figs. 32-6). 
The 'Nebenkern' of Yamanouchi (24) in Nephrodium and the nucleolus-like body described by Webber (20) in Ginkgo are possibly homologous with the 'Nebenkörper' (Ikeno) or 'limosphere' (Wilson), and in the higher plants may have lost its original function, as the former authors agree that it takes no part in the formation of the spermatozoid.

The final changes which take place within the spermatid of Polytrichum will now be described. When the arched band is fully developed, the nucleus undergoes a marked change in form. Fig. $3^{6}$ shows an early phase of this change where the nucleus is drawn out into a pointed process which is directed backwards. This elongation continues and the nucleus becomes extended upon the arched band until its anterior rounded extremity reaches the blepharoplast (Figs. 37 and 38). This band-like organ, hitherto so prominent, now appears less marked (Figs. 37-9), especially that portion adjoining the thicker part of the nucleus (Fig. $3^{8}$ ), and in some spermatids is seen to have completely disappeared from this region (Fig. 37). It seems probable that the substance of the curved band has been reabsorbed by the nucleus, which from this point onwards stains more and more deeply (Figs. $3^{8}$ and 39). The process of elongation of the nucleus continues until it takes the form of a thick curved rod (Fig. 39).

In Chara a structure somewhat resembling the arched band of Polytrichum in form and in its relation to the nucleus is described by Mottier (15), and is regarded by him as a blepharoplast. This interpretation seems impossible in Polytrichum, where the band disappears before the cilia are developed. A superficial resemblance is also seen between the curved band of the Polytrichum spermatid and the coiled band formed by the elongation of the blepharoplast, described by Yamanouchi in Nephrodium.

The body of the developing spermatozoid continues to lengthen and its anterior end is carried into the region of the vesicle or persistent 'Nebenkörper' attached to the opposite extremity of the spermatozoid. The blepharoplast, which has now lost its refractive character, is thus obscured, and its further fate is difficult to follow. At a later stage, when many of the spermatozoids which now bear cilia appear less closely coiled, each is seen to terminate in front in a minute slightly elongate particle, probably the remains of the blepharoplast, behind which is a narrow feebly stained region (Fig. 40). Occasionally the cilia could be traced to this terminal particle, but very few spermatozoids in the sections displayed this region sufficiently clearly to make a determination of the exact place of insertion possible. The body of the spermatozoid is now extremely slender and stains uniformly throughout.

The spermatozoid has now completed its development and consists of a spirally coiled band derived from the nucleus, carrying a pair of cilia at its anterior extremity, and at the posterior end the remains of the deeply stained sphere or 'Nebenkörper' which was originally extruded from the nucleus. 


\section{The Escape of the Ripe Spermatozoids.}

Free spermatozoids have been found unexpectedly difficult to obtain. In from seven to ten minutes after a drop of distilled water has been placed upon the open cup-like antheridial rosette, one or more rope-like masses are seen to arise from the bottom of the cup. These emerge from between the numerous imbricating involucral leaves whose tips form the sides and floor of the cup. On transference of the drop of water to a slide by means of a pipette, the cylindrical masses break up into fragments of various sizes. Fig. 4I was drawn from a single small fragment. Each fragment consists of a mucilaginous matrix in which occur numerous spherical cavities. In each cavity is a spermatozoid in active movement. The mucilage is the result of the swelling of the outer layers of the thick walls of the spermatids, while the innermost region of the wall remains firm and tenacious and forms a delicate vesicle within which the spermatozoid is imprisoned. These vesicles are easily demonstrated by covering the drop with a cover-glass, when many of them are separated from the mucilage and are dispersed in the surrounding fluid. The spermatozoid is coiled within this bladder-like sac with its body pressed against the wall, and occupies about one and a half turns of a spiral. Fig. 4I shows a spermatozoid at this stage. The cilia whose rapid vibration renders them invisible are not shown in the drawing. Shortly after the escape of the mucilage from the antheridia, the spermatozoids, lying within their vesicles, commence a rapid movement, the narrow or ciliated end advancing foremost. When this movement is sufficiently rapid, the outward pressure exerted upon the wall of the vesicle would bring about its rupture and free the spermatozoid. This, however, does not seem to be a common occurrence. In experiments performed in the laboratory, only an occasional spermatozoid succeeds in liberating itself. Many antheridial cups were treated in the manner described without the escape of a single spermatozoid from its vesicle. Antheridial cups were filled with tap-water and with distilled water, treated in various ways, such as filtration through animal charcoal, thorough shaking with air and with oxygen, and the addition of cane sugar; but by none of these methods were the spermatozoids stimulated to make their escape. The best result was obtained by the use of rain-water collected in a vessel placed upon the roof of the University of Leeds during a Sunday morning after forty-eight hours of continuous rain. Under these conditions, the rain-water of Leeds would most nearly resemble that of the districts where Polytrichum flourishes and succeeds in forming sporogonia. The spermatozoid sketched (Fig. 42) resulted from this experiment. During several visits to Sedbergh in north-west Yorkshire made with the intention of determining the effect of local rain upon the escape of the spermatozoids, the weather unfortunately remained fine, and rain did not fall during any of 
the visits. Through the kindness and hospitality of $\mathrm{Mr}$. Wager, experiments were performed upon Polytrichum commune at Hawkswick, near Grassington, during the rainy Whitsuntide of 1912. The withdrawal and microscopic examination of the rain-water which had fallen upon ten antheridial rosettes resulted in the discovery of one free spermatozoid. It is probable, however, that the ripe spermatozoids of these rosettes had already been nearly exhausted during the preceding wet weather, as the extruded mucilage with imprisoned spermatozoids was not so abundant as when obtained in the laboratory from material kept for a few days under a bell-jar. Observations will be made when opportunity offers, to determine the effect of the local rain-water upon rosettes after fair weather, when many of the antheridia will be ready to discharge. Under favourable conditions an enormous number of spermatozoids is extruded from the antheridia of each rosette and a great wastage must result through the difficulty of their escape from the vesicles. It is possible that only the most vigorous specimens are thus selected for the operation of fertilization.

The body of the escaped spermatozoid occupies somewhat less than a complete turn of a spiral and moves sluggishly corkscrew-wise through the water, ciliated end foremost. The vesicle of substance attached to the tail of the spermatozoid seems to effect a drag upon its movement and may afford nourishment during the long journey of the spermatozoid to an archegonial plant. The greater part of the distance is probably covered by means of the splashing of the rain, which would transfer spermatozoidcontaining water from the very numerous antheridial rosettes to the drops of water which lodge upon the summits of the adjoining archegonial plants.

I desire to thank Professor V. H. Blackman for many kindnesses and for his helpful advice given during the course of the investigation. My obligations are also due to Mr. G. H. Elam of Sedbergh, for his assistance in connexion with the collection of material.

\section{SUMMARY.}

I. In Polytrichum formosum no fusion was observed to take place between the egg-cell and the large ventral canal cell. The fusion appearances described by $\mathrm{J}$. and $\mathrm{W}$. van Leeuwen-Reijnvaan are probably due to their special method of preparation of the material before fixation.

2. In the spermatogenic cells the nucleus contains a large nucleoluslike body in which almost the whole of the chromatin is stored. This is connected with a peripheral reticulum by delicate radiating threads.

3. During the prophase of division the chromatin is passed along the radiating threads to certain threads of the reticulum, which consequently thicken, and from these the spireme is organized. 
4. The number of chromosomes is six, and there is no reduction of their number during the last division of the spermatogenic cells.

5. During the reconstitution of the daughter nuclei the chromosomes show an end-to-end union, and by the development of anastomosing threads a simple reticulum is formed. The chromatin gradually leaves this reticulum and collects to form the central nucleolus-like mass.

6. During the anaphase of the last division of the spermatogenic cells a relatively large particle of chromatin is generally detached from each of the daughter chromosome groups, and is passed out into the cytoplasm.

7. Centrosome-like bodies occupy the poles of the spindle during the last division, but are not present during the earlier divisions.

8. The centrosome-like particle persists in the spermatid and becomes the blepharoplast.

9. An extra division was observed in two antheridia, and this is preceded by the division of the blepharoplast. The daughter particles did not in all cases occupy the poles of the spindle during this division.

IO. The young spermatid contains, in addition to the nucleus, a conspicuous blepharoplast. The greater part of the chromatin is now passed from the nucleus into the cytoplasm and collects in the form of two spherical masses, which correspond to the single ' Nebenkörper' of Ikeno.

II. An arched band-like organ is next developed, probably at the expense of the extruded chromatin bodies, one of which is consumed in the process. This band passes round the periphery of the spermatid and joins the blepharoplast, thus connecting this body with the remaining mass of extruded chromatin. The nucleus is enclosed within the arch.

I2. The nucleus of the spermatid becomes drawn out along the arched band and the greater part of the latter is reabsorbed by the nucleus.

I3. The nucleus undergoes further elongation to form the body of the spermatozoid, which ultimately occupies about one and a half turns of a spiral. At the anterior extremity occurs a minute particle which is probably the remains of the blepharoplast, and in the region of this particle the two long cilia are inserted. At the posterior extremity of the spermatozoid is a conspicuous vesicle which consists mainly of the remaining spherical mass of extruded chromatin.

I4. In the presence of water, the ripe antheridium extrudes a mucilaginous mass, in which the spermatozoids are imprisoned. Each spermatozoid rapidly revolves within a spherical vesicle, possessing a somewhat tenacious wall, and in laboratory experiments the spermatozoids rarely succeeded in making their escape from their vesicles.

The UNIVERSITY,

LEEDS. 


\section{REFERENCES.}

1. Allen, C. E. : Cell Structure, Growth, and Division in the Antheridia of Polytrichum juniperinum, Willd. Archiv f. Zellforsch., Bd. viii, I9I2, p. I 2 I.

2. Arens, P.: Zur Spermatogenese der Laubmoose. Ref., Bot. Centralbl., Bd. cvii, 1908, p. 611.

3. Beer, R. : On the Development of the Spores of Riccia glauca. Ann. of Bot., xx, I906, p. 275 .

4. BelajefF, W.: Ueber Bau und Entwickelung der Spermatozoiden der Pfanzen. Flora, Bd. lxxix, I894, p. I.

5. Bolleter, E. : Fegatella conica, (L.) Corda. Eine morphologisch-physiologische Monographie. Beih. z. Bot. Centralbl., Bd. xvii, 1905 , p. 348.

6. Escoyez, E. : Blépharoplaste et centrosome dans le Marchantia polymorpha. La Cellule, t. xxiv, fasc. 2, p. 247. Ref., Bot. Centralbl., Bd. cv, 1907, p. 594.

7. Fraser, H. C. I., and Snell, J. : The Vegetative Divisions in Vicia Faba. Ann. of Bot., vol. $\mathrm{xxv}, \mathrm{I} 9 \mathrm{II}, \mathrm{p} .845$.

8. Grégoire, V., and Wygaerts, A. : La reconstruction du noyau et la formation des chromosomes dans les cinèses somatiques. La Cellule, t. xxi, fasc. I, I903, p. 7 .

9. Ikeno, S.: Die Spermatogenese von Marchantia polymorpha. Beih. z. Bot. Centralbl., xv, 1903, p. 65 .

10. - Are the Centrosomes in the Antheridial Cells of Marchantia polymorpha imaginary? Bot. Mag., Tokyo, vol. xix, 1905, p. I I I. Ref., Bot. Centralbl., Bd. ci, I906, p. I94.

11. Humphrey, E. B. : The Development of Fossombronia longiseta, Aust. Ann. of Bot., vol. xx, 1906, p. 83 .

12. Leeuwen-ReijnvaAn, J. and W. van : Ueber eine zweifache Reduktion bei der Bildung der Geschlechtszellen und darauf folgende Befruchtung mittels zwei Spermatozoiden und über die Individualität der Chromosomen bei einigen Polytrichum-Arten. Recueil des trav. bot. néerl., t. iv, I908, p. I77.

13. Martins Mano, T.: Nucléole et chromosomes dans le méristème radiculaire de Solanum tuberosum et Phaseolus vulgaris. La Cellule, t. xxii, fasc. I, I904, p. 57.

14. Mipake, K.: On the Centrosome of the Hepaticae. Bot. Mag., Tokyo, vol. xix, I905, p. 98. Ref., Bot. Centralbl., Bd. ci, 1906, p. 194.

15. Mottier, D. M. : Development of the Spermatozoid in Chara. Ann. of Bot., vol. xviii, I904, p. 245 .

16. Strasburger, E.: Zeitpunkt der Bestimmung des Geschlechts, Apogamie, Parthenogenesis und Reduktionsteilung. Jena, I909.

17. — : Schwärmsporen, Gameten, pflanzliche Spermatozoiden und das Wesen der Befruchtung. Jena, I892.

18. Van Hook, J. M.: Notes on the Cell and Nucleus in Liverworts. Bot. Gaz., vol. xxx, I900, p. 394 .

19. Wager, H.: The Nucleus and Nuclear Division in the Root-apex of Phaseolus. Ann. of Bot., vol. xviii, 1904, p. 29.

20. Webber, H. J.: Notes on the Fecundation of Zamia and the Pollen-tube Apparatus of Ginkgo. Bot. Gaz., vol. xxiv, 1897 , p. 225 .

21. Wilson, M.: Spore Formation and Nuclear Division in Mnium hornum. Ann. of Bot., vol. xxiii, 1909, p. I4J.

22. - Spermatogenesis in the Bryophyta. Ann. of Bot., vol. xxv, I9II, p. 4I5.

23. Woodburn, W. L. : Spermatogenesis in certain Hepaticae. Ann. of Bot., vol. xxv, IgII, p. 299.

24. Yamanouchi, S.: Spermatogenesis, Oogenesis, and Fertilization in Nephrodium. Bot. Gaz., vol. xlv, 1908, p. 289. 


\title{
EXPLANATION OF FIGURES IN PLATES XIII AND XIV.
}

\author{
Illustrating Mr. Walker's paper on Polytrichum.
}

The figures were drawn with the help of a camera lucida under a Leitz $\frac{1}{12} a$ objective, N. A. I.32 with Zeiss comp. oc. 12, $\times$ 3,000, except Fig. 40, which was drawn under a Zeiss apo. 2 mm. N. A. $I \cdot 40, \times 2,500$.

Figs. I-I 2 were drawn from spermatogenic cells of antheridia in various stages of development, anterior to the last division. Figs. 13-23 refer to the last division. Figs. 24-6 show the extra division; Figs. 27-42 the development of the spermatozoid. All refer to Polytrichum formosum, Hedw.

\section{PLATE XIII.}

Fig. I. Cell from a very young antheridium, showing nucleus and remains of chloroplasts.

Fig. 2. Nucleus; central nucleolus, radiating threads and peripheral reticulum.

Fig. 3. Cell containing nucleus with large nucleolus and obscured reticulum.

Fig. 4. Cell with nucleus in the spireme stage.

Fig. 5. Cell with nucleus in the spireme stage; early spindle fibres.

Fig. 6. Segmentation of spireme.

Fig. 7. Polar view of dividing nucleus, showing six chromosomes.

Fig. 8. Metaphase in side view.

Fig. 9. Early anaphase in side view.

Figs. IO and I r. Telophases; chromatin leaving reticulum.

Fig. I2. Daughter nucleus with outstanding particle of chromatin.

Fig. I3. Early prophase of last division of spermatogenic nucleus; centrosomes; chromatin leaving nucleolus.

Figs. I4 and I5. Early prophases; distribution of chromatin to peripheral reticulum.

Fig. I6. Early spireme; anastomosing threads still present.

Fig. 17. Nucleus with nucleolus after distribution of the chromatin to the reticulum.

Fig. 18. Anaphase of last division; centrosomes at poles of spindle.

Fig. 19. Telophase of last division; side view of spindle, showing detachment of chromatin particle from one of the chromosome groups.

Fig. 20. Polar view of nuclei in telophase ; detached particles lying in the cytoplasm; end-toend union of chromosomes, and development of anastomosing threads.

Fig. 2I. Danghter chromosomes in telophase of last division, showing end-to-end union of five chromosomes.

Fig. 22. Telophase; side view of spindle; union of chromosomes to form a simple spireme-like structure; detached chromatin particles.

Fig. 23. Two cells after last division, lying in a common chamber with mucilaginous walls; persistent centrosomes.

Fig. 24. Prophase of abnormal extra division; blepharoplast dividing.

Fig. 25. Metaphase of same, showing blepharoplasts at poles of spindle.

Fig. 26. Metaphase of same division, showing one of the blepharoplasts lying away from the spindle pole.

Fig. 27. Early spermatid with blepharoplast.

Fig. 28. Later spermatid with chromatin aggregated towards the centre of the nucleus.

Fig. 29. Spermatid showing extrusion of chromatin from the nucleus.

\section{PLATE XIV.}

Fig. 30. Spermatid showing later stage of extrusion of chromatin.

Fig. 31. Extruded chromatin in two spherical masses lying in the cytoplasm.

Figs. 32-4. Stages in the development of the arched band. 
I32 Walker.-On Abnormal Cell-fusion and Spermatogenesis.

Fig. 35. Dorsal view of spermatid; arched band passing from the chromatin vesicle to the blepharoplast, and enclosing the nucleus.

Figs. $3^{6-9}$. Stages in the elongation of the nuclens along the arched band, with the absorption of the latter body by the nucleus.

Fig. 40. Spermatozoid, drawn from a stained section of a ripe antheridium; blepharoplast with cilia at the fore end, and chromatin vesicle at the hinder end.

Fig. 4I. Fragment of the mucilage extruded from an antheridium, showing the spherical vesicles and a spermatozoid drawn in one only.

Fig. 42. Mature spermatozoid; drawn from a living example. 
Annals of Botany.
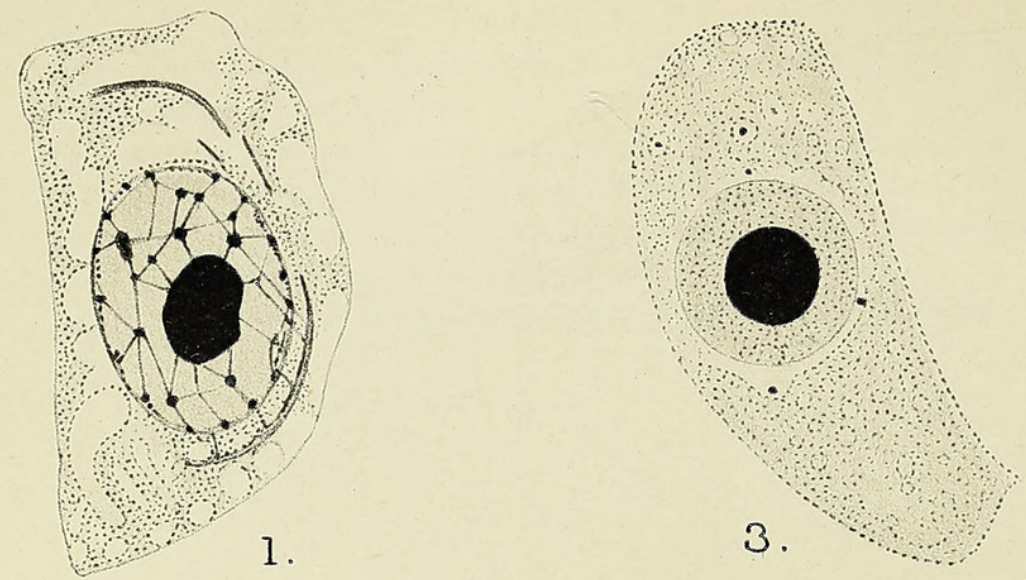

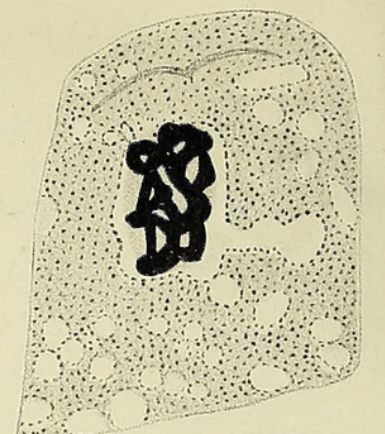

4

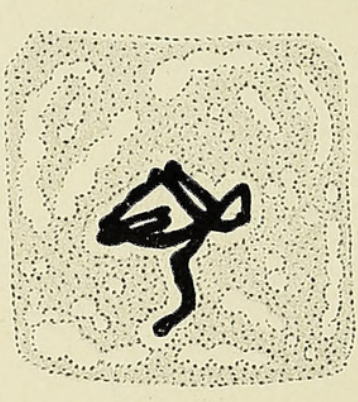

6.

.

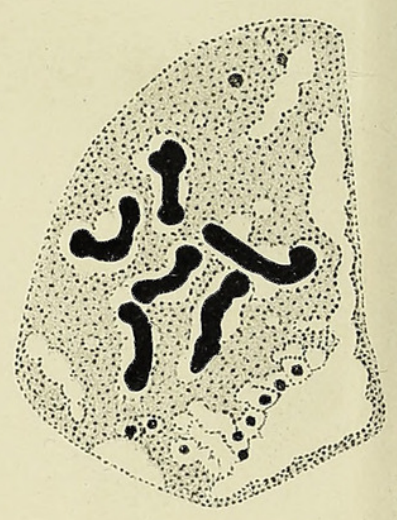

7.

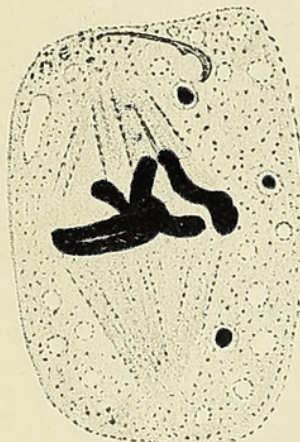

8.

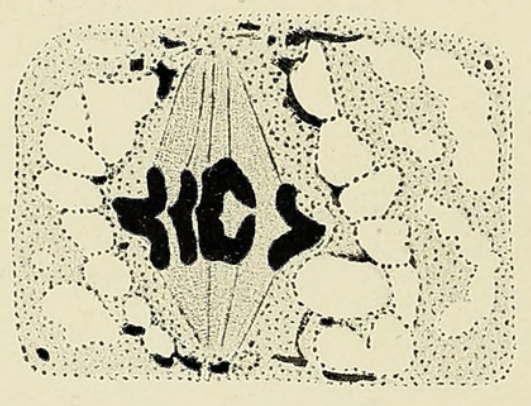

9.

\section{8}

10.

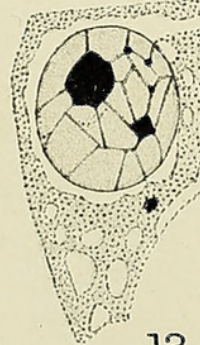

12.
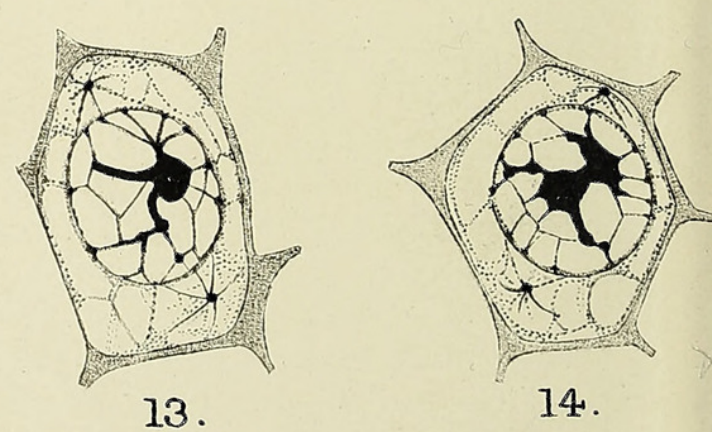

N.W.del. WALKER. POLYTRICHUM. 


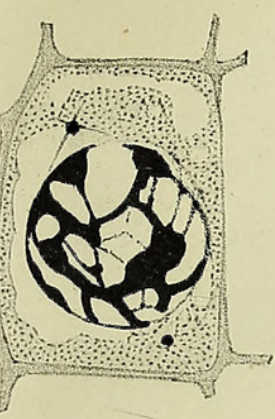

15.

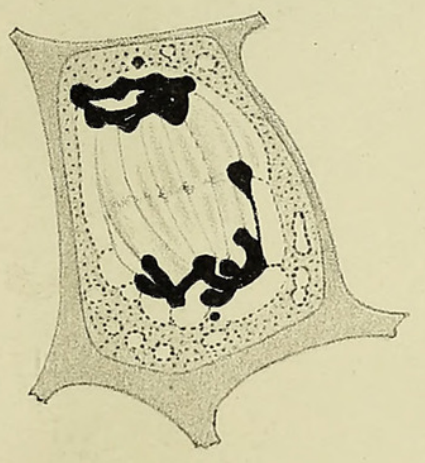

19.

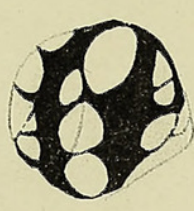

16.

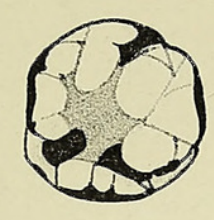

17.

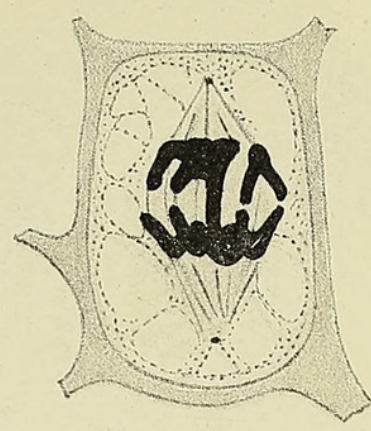

18.

21.

$$
20 .
$$

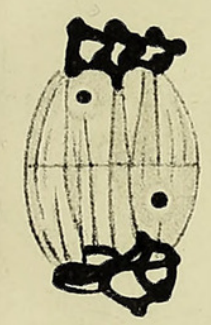

22.

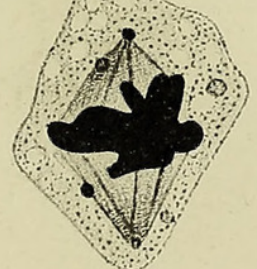

26.

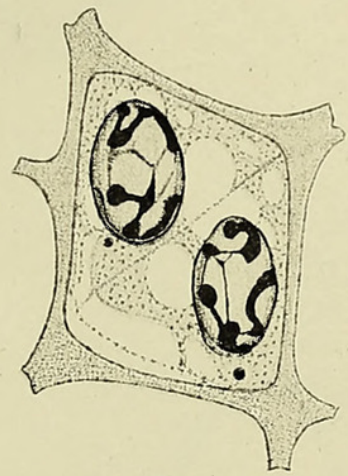

23.

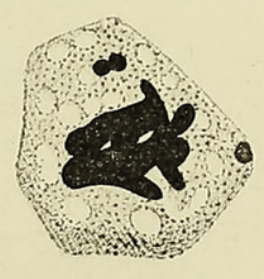

24.

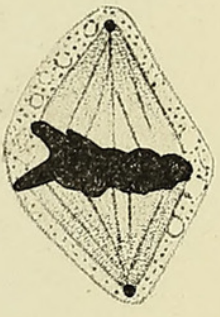

25.

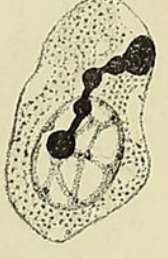

29.

Huth, Iithet imp. 


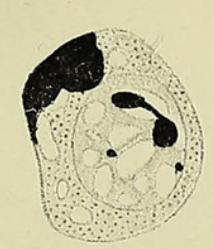

30.

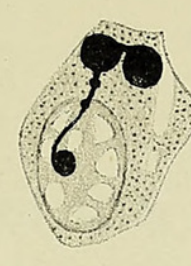

31.

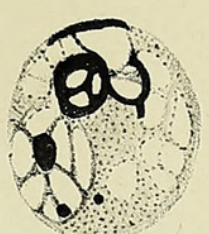

32.

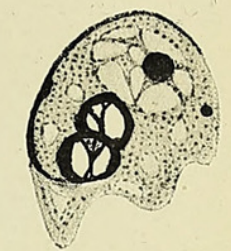

33.

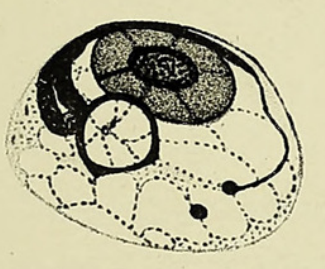

34.

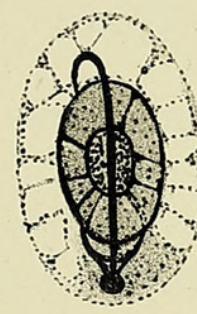

35.

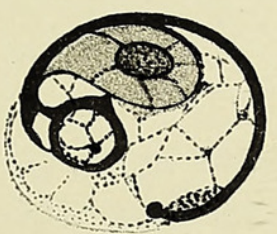

36.

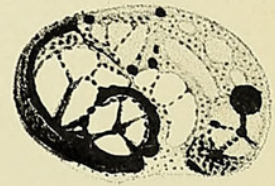

37.

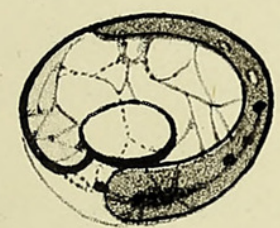

38.

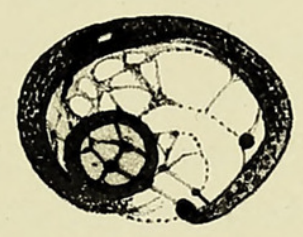

39.

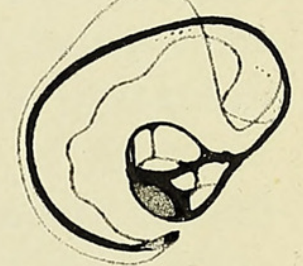

40
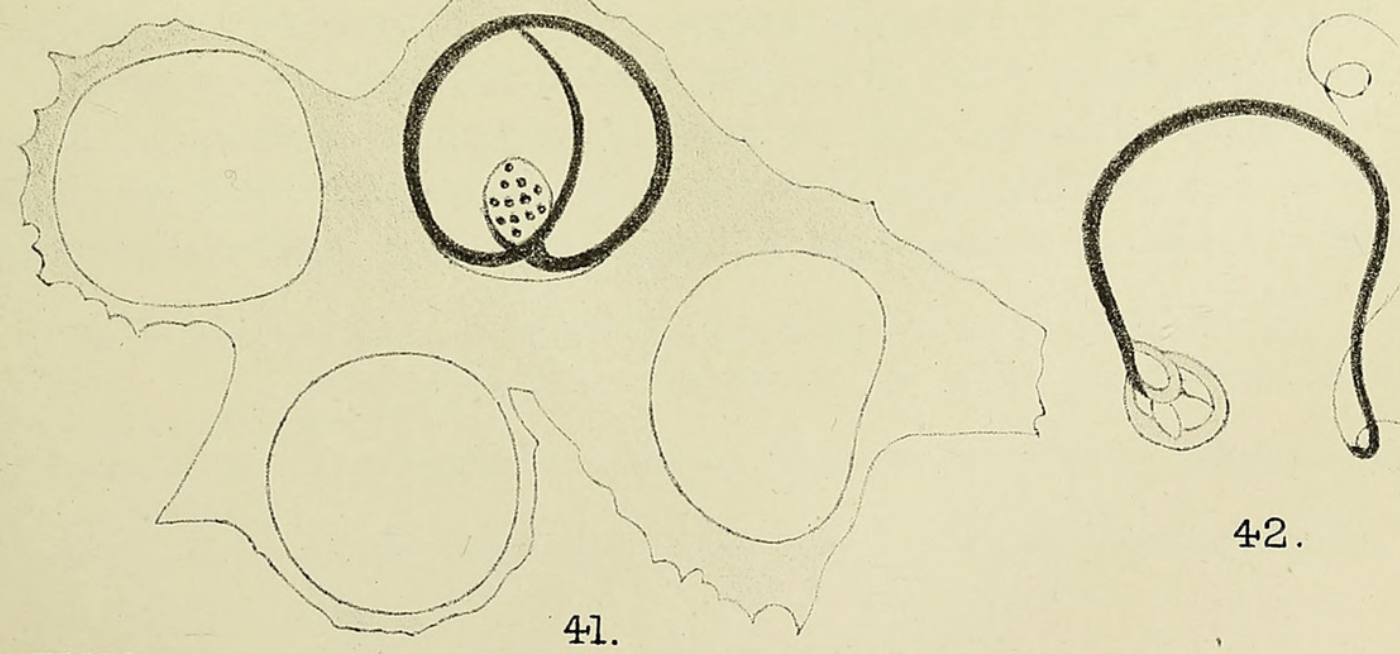

42. 


\section{$2 \mathrm{BHL}$ Biodiversity Heritage Library}

Walker, Norman. 1913. "On abnormal cell-fusion in the Archegonium; and on spermatogenesis in Polytrichum." Annals of botany 27, 115-132. https://doi.org/10.1093/oxfordjournals.aob.a089445.

View This Item Online: https://www.biodiversitylibrary.org/item/237410

DOI: https://doi.org/10.1093/oxfordjournals.aob.a089445

Permalink: https://www.biodiversitylibrary.org/partpdf/319961

\section{Holding Institution}

Smithsonian Libraries

\section{Sponsored by}

Biodiversity Heritage Library

\section{Copyright \& Reuse}

Copyright Status: Not in copyright. The BHL knows of no copyright restrictions on this item.

This document was created from content at the Biodiversity Heritage Library, the world's largest open access digital library for biodiversity literature and archives. Visit BHL at https://www.biodiversitylibrary.org. 